The BDJ News section accepts items that include general news, latest research and diary events that interest our readers. Press releases or articles may be edited, and should include a colour photograph if possible. Please direct your correspondence to the News Editor, Arveen Bajaj at the BDJ, 64 Wimpole Street WIG 8YS or by e-mail to bdj@bda.org

\section{Standards for dental practice}

The GDC is consulting on its new draft guidance for members of the dental team, Standards for Dental Practice.

It proposes to have single core guidance in the future, of which Standards for Dental Practice is the prototype, which will apply to all dental professionals and will replace the current guidance, Maintaining Standards.

Describing the key principles for safe, ethical practice, the guidance will underpin all other future guidance issued by the Council and will be complemented by a series of additional booklets, including guidance on the individual responsibilities of those working in the dental team.

The GDC is welcoming views on both the content and format of this draft guidance and, in particular, views about the Council's new approach to publishing professional guidance, whether the purpose and status of the Council's draft guidance is clear, whether the draft guidance is understandable, and whether the new A5 booklet format is easy to use.

The consultation document is on the GDC's website: http://www.gdc-uk.org/ aboutus/gdc_consultations.html where a response form is provided and the closing date for consultation is 15 December 2003.

For those who want to find out who's who at the GDC, photographs and biographies of Council members are available by logging on to the 'About us' section of the GDC website at www.gdc-uk.org. The GDC plans to expand this section of the site in the future and will be adding details of the Council's committee structure and membership, plus profiles of the members of the new Fitness to Practise Panel.

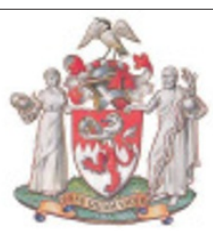

General Dental Council

\section{And the winner is...}

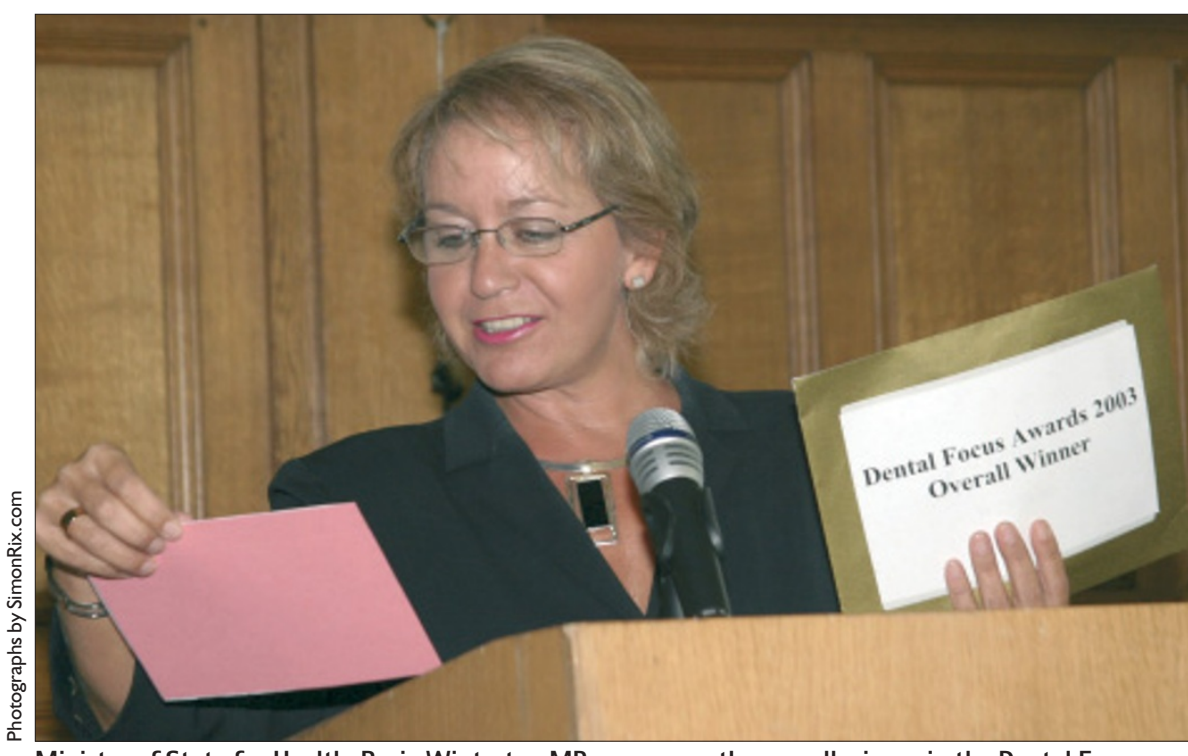

Minister of State for Health, Rosie Winterton MP announces the overall winner in the Dental Focus Awards 2003. The awards were organised by the BDA, the Department of Health, the Welsh Assembley Government and the Department of Health, Social Services and Public Safety Northern Ireland to recognise commitment to NHS dentistry. Representatives of the winning teams gathered at the $\mathrm{Cl}$ Insurance Hall in the City of London to receive their awards from leading figures in the dental community. As well as Rosie Winterton, these included Chairman of the BDA's Executive Board Dr John Renshaw and Chief Dental Officer for England Professor Raman Bedi. (For more on the award winners see over page).

\section{Step in the right direction}

The government is to invest $£ 65.2 \mathrm{~m}$ to improve access to and increase the quality of NHS dental services, a move welcomed by the BDA as a step in the right direction.

Around $€ 35 \mathrm{~m}$ will be used to enable Primary Care Trusts to improve access, choice and quality for patients in areas that have problems, while $£ 30 \mathrm{~m}$ will be used for information technology to integrate dentistry within the national NHS IT programme. The remaining $£ 200,000$ will go towards developing dental leadership skills within Strategic Health Authorities and Primary Care Trusts to support them with the dental change agenda.

The BDA was pleased to see the inclusion of funding for information technology within the announcement as dentists' use of electronic records is

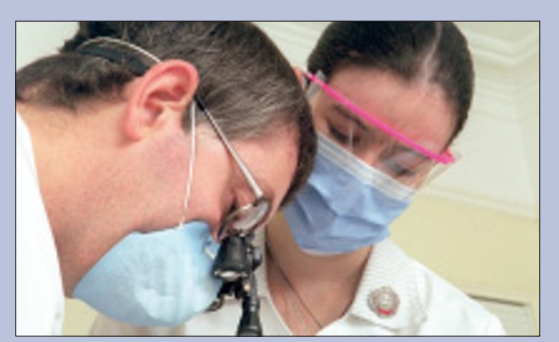

already widespread and this injection of funding will assist with their integration within the wider NHS IT strategy.

According to the BDA's chief executive Ian Wylie, though the funding will go some way to help boost the morale of dentists working in the NHS, the BDA will continue to press the Government for greater investment in training places for dentistry, as well as better terms and conditions to encourage recruitment and retention of dentists within the NHS. 


\section{DIARY}

October 2003

International Conference on Evidence-

based Advanced Dentistry

Date: 31.10.03-03.11.03

Venue: Hong Kong

Tel: +44 (852) 28718787

Fax: +44 (852) 28718898

E-mail: confdept@hkam.org.hk

November 2003

Removable Partial Dentures

Date: 14.11 .03

Venue: The Aztec Hotel, Bristol

Contact: Events Office,

British Dental Association

Tel: +44 (0) 2075634590

E-mail: events@bda.org

National Association of Dental Advisers Conference 2003

Date: 20-21.11.03

Venue: Jurys Bristol Hotel

Contact: Events Office,

British Dental Association

Tel: +44 (0) 2075634590

E-mail:events@bda.org

\section{May 2004}

BDA National Annual Conference

Date: 06.05.04 - 08-05.04

Contact: Events Office,

British Dental Association

Venue: Bournemouth International

Centre

Tel: +44 (0) 2075634590

Fax: +44 (0) 2075634591

E-mail: events@bda.org

\section{CRHP launches consultation exercise}

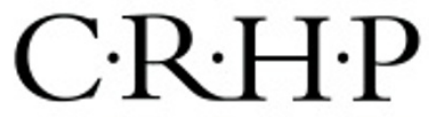

COUNCIL FOR THE REGULATION OF HEALTHCARE PROFESSIONALS

A new independent body established to strengthen the regulation of healthcare professionals in the UK launched its first consultation exercise last month.

The Council for the Regulation of Healthcare Professionals (CRHP) has powers to refer decisions on cases heard by regulatory bodies to the High Court in England or equivalent court elsewhere in the UK if it believes this is necessary to protect the public because the regulator has been too lenient.

In practice, it is likely that only a handful of very serious cases will be referred each year. The CRHP has 19 members, including nominees from each of the regulatory bodies regulating healthcare professionals and ten lay members.

The consultation is on procedures to be used by the Council in the very rare event of referring what is called a 'relevant' decision by a regulator. A relevant decision is a final decision by a regulatory fitness to practise committee on a practitioner's conduct or performance.
The CRHP may refer a case to court if it thinks that a referral is desirable for the protection of the public and that the regulator's decision may have been unduly lenient or erroneous.

The consultation document emphasises that only a very small number of cases are expected to be referred, and that the CRHP has only a short period after the conclusion of the regulatory case to decide whether to take any further action.

It is consulting with the nine regulatory bodies in the UK - including the GDC - and a wide range of other professional, lay and consumer interests who have already been involved in preparing the proposals for wider consultation.

Consultation started on 16 September with a closing date for comments of 15 December 2003. The consultation document is on the CRHP website at www.crhp.org.uk.

The CRHP is independent of the Government and reports annually to Parliament. Powers to refer cases were granted under Section 29 of the Act to create CRHP which came into being on 1 April 2003.

It claims its main purpose is to promote the interests of patients and the wider public in the regulation of the health professions, to stimulate good practice in regulation and to strengthen the trust placed in the professionals who care for patients. 


\section{Focus Award winners}
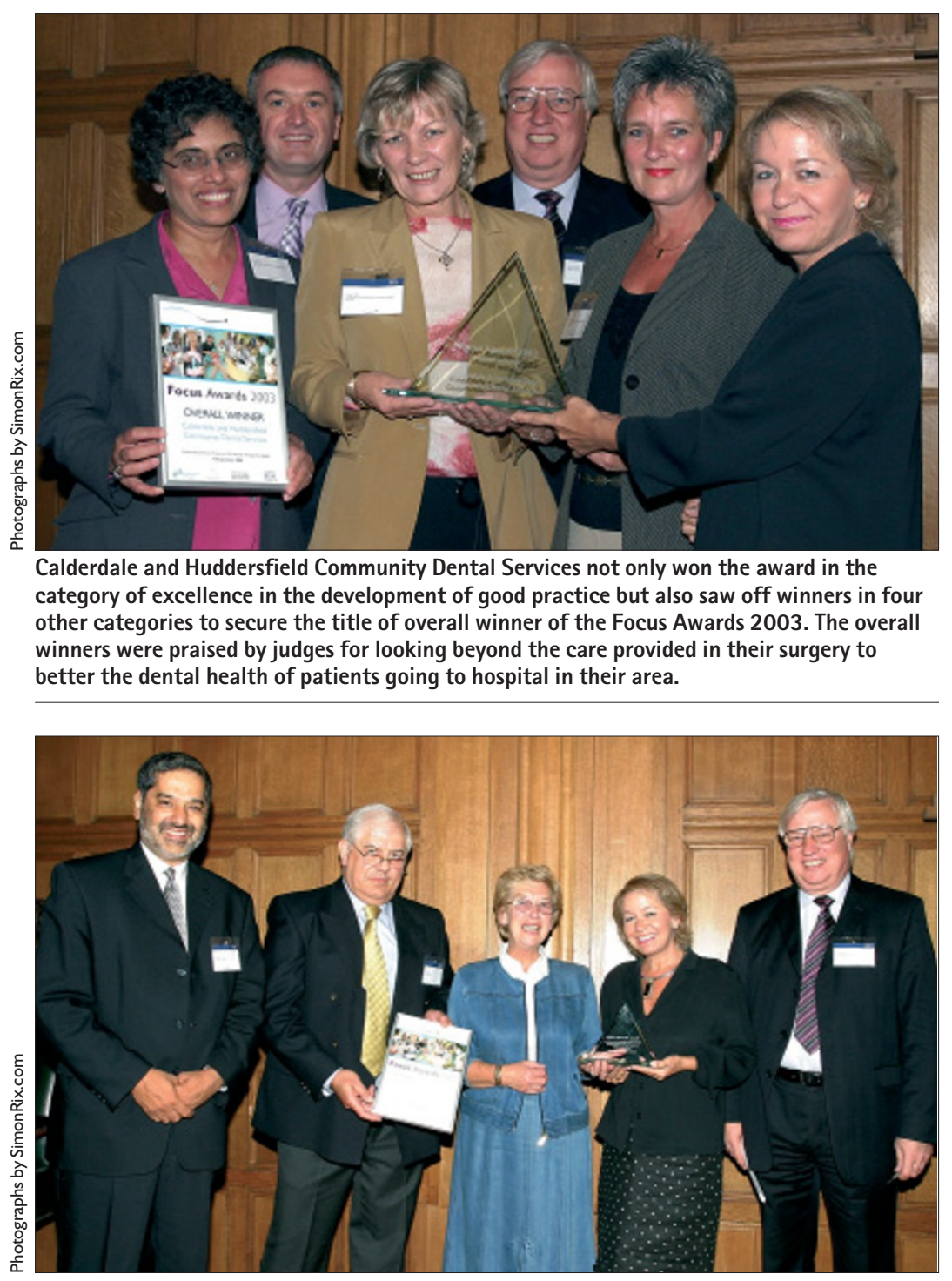

The Zetland House Clinic from Northallerton won the award in the category of excellence in treating those patients with special healthcare needs. The team developed strong

relationships with two of North Yorkshire's schools for children with special needs allowing them to provide an effective oral healthcare service.

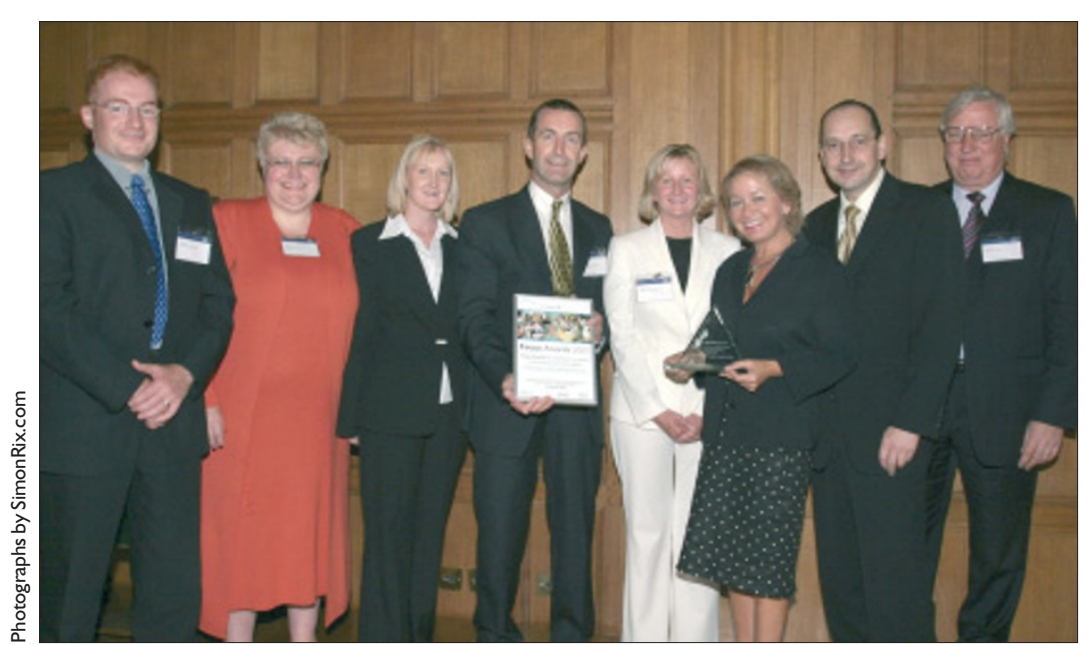

Wessington Way Dental Practice from Sunderland won the award for excellence in patient information and involvement. Overall winners of the awards last year, interaction between the dental team and patients has been developed by many initiatives supported by a practice newsletter, website, leaflets and patient information board. 